\title{
Scanning Electron Microscopy of Mineralized Cartilage in Rat Mandibular Condyle
}

\author{
Keith S. Lester and Major M. Ash, JR. \\ Department of Occlusion, University of Michigan School of Dentistry, Ann Arbor, Michigan 48109
}

Received March 24, 1980

\begin{abstract}
The pattern of mineralization was studied in the mandibular condyle of the young adult rat. Specimens were rendered anorganic in $\mathrm{NaOCl}$ and examined in a scanning electron microscope. A mineralized cartilage front was found to persist on the articular aspect of the condyle. The surface is characterized by closely approximating chondrocyte lacunae enclosed to different degrees within the mineralized front. The mineralized component itself is calcospheritic; larger calcospherites forming the inner concave wall and smaller calcospherites forming the outer convex wall. The calcospherites are comprised of irregular crystalline plates radiating from the center of the mass. The bony surface of the ramus immediately beneath the condyle is typified by Howship's lacunae alternating with areas of forming bone indicating intense remodeling activity. The mandibular condyle has not been examined in this way before. The information is relevant to consideration of growth and development, functional adaptation, physiological aging, and pathological change.
\end{abstract}

The articulating surface of the mandibular condyle is dense fibrous tissue and not hyaline cartilage as with most other synovial joints $(28,96)$. Scanning electron microscope (SEM) studies of the mandibular condyle have to date been restricted to this outer layer of organic material $(52,86)$. Resolveable detail at this undoubtedly vacuum-affected surface $(16,37)$ is limited. There is no SEM information currently available on the underlying mineralized component of the mandibular condyle, although anorganic preparations of normal $(15,20,70)$ and pathological (71) epiphyseal and metaphyseal cartilage have been described.

The aim of this study was to examine the pattern of mineralization in the mandibular condyle.

\section{MATERIALS AND METHODS}

The mandibular condyles of six young adult (264day old) rats (Rattus norvegicus) were dissected post. mortem after their being subjected to ether inhalation. Condyles were placed in a cold solution of $5.25 \%$ sodium hypochlorite (Clorox), changed daily, for a period of 4 days. The specimens were gently washed in several changes of distilled water to remove sodium chloride; dehydrated through graded ethanols to ab- solute; air dried and given a conducting coat of gold in an argon-ion atmosphere (Polaron sputter coater E5100-Polaron Instruments Inc., Watford, Hertfordshire, U.K.). The specimens were examined in a JEOL JSM-U3 at $15 \mathrm{kV}$ and stereo+pair photomicrographs were taken at a tilt angle difference of $5^{\circ}$ where appropriate.

\section{RESULTS}

The outer (articular) surface of the mandibular condyle of the rat, after exposure to $\mathrm{NaOCl}$ and examination in the SEM, is characterized by a multitude of irregularly shaped, closely packed openings of varying size (ca. 1.5 to $15 \mu \mathrm{m}$ ) (Figs. 1-3). The openings populate the entire surface except for occasional, more amorphous patches and some minor furrowing presumably of vascular origin. The openings represent spaces previously occupied by the dissolved cellular component of the mineralized cartilage plate. The empty chondrocyte lacunae are in varying stages of closure from open, shallow depressions to almost completed shells, the latter with very small openings in their outer walls or roofs (Fig. 4). Areas containing largely roofed-over lacunae correspond to the more amorphous patches seen at low magnification (Fig. 1). 
The basic structural unit seen at higher magnification is irregularly spheritic (Figs. $5-8$ ). These roughly globular masses (calcospherites) occur in two orders of size dependent on location. The calcospherites are larger (up to $2 \mu \mathrm{m}$ with an average diameter of $1.5 \mu \mathrm{m})$ in the exposed, inner, concave walls of open, shallow lacunae (Fig. 6). The calcospherites are smallest (up to $1.2 \mu \mathrm{m}$ with an average diameter of $0.8 \mu \mathrm{m}$ ) on the outer, convex walls of nearly enclosed lacunae (Fig. 9). This size difference is consistent and characteristic of the two locations. The calcospherites are composed of irregularly oriented, sometimes wavy, thin plates radiating from within the mass. The smaller calcospherites forming the roofs of completed lacunae consist of relatively fewer, thicker plates compared to the larger calcospherites (cf. Figs. 6, 9).

Extensive discontinuities often exist within the inner walls or floors of open lacunae (Fig. 7). Much smaller deficiencies occur in the outer walls of closed lacunae (Fig. 8). Adjacent lacunar cavities are sometimes incompletely walled off from each other, this being more readily visible within the open, shallower type.

The junction between the mineralized cartilage surface of the condyle and the mineralized subperiosteal bone of the ramus is sudden and marked (Figs. 10, 11). Apart from the obvious morphological differences between mineralized cartilage and a very active bone surface, there is some lipping of the junctional edge and a large number of channels, presumably of vascular origin.

Osteoclastic activity is intense on the bony surface, Howship's lacunae being the predominant structural feature (Figs. 12, 13). There are areas of forming bone (repair) between the resorptive sites.

\section{DISCUSSION}

Anorganic rat mandibular condyle examined in the SEM exhibits a mineralized front of cartilage persisting in the young adult as a complete covering. The surface is characterized by a multitude of chondrocyte lacunae enclosed to different degrees within the mineralizing front. The mineralized component itself is calcospheritic, larger calcospherites forming the inner, concave wall (floor or bed) and smaller calcospherites forming the outer, convex wall (or roof). To our knowledge, the mandibular condyle has not been examined in this manner previously nor have the details of calcified cartilage been similarly resolved.

Structures which could be interpreted as calcospherites have been described by electron microscopy in a variety of tissues and given many names. Some of the more recent terms, often used interchangeably, are: ossicles (74); spherites (87); crystallite clusters $(10)$; spheroidal bone nodules $(5,6)$; calcifying globules $(11,12,71)$; mineralized spherules (55); calcifying nodules (90); calcified globular structures (82); spherical mineral clusters (36); calcification nodules (65); and spherules (57). Interestingly, the term "calcospherite" (diam 0.1 to $0.3 \mu \mathrm{m}$ ) has been used to describe the surface particulate pattern of a "calcified globular structure" ( 1 to $3 \mu \mathrm{m}$ ) (82). This last rather begs the question of relative size and whether one can continue to group the calcospherites of, say, dentine (diam up to 100 $\mu \mathrm{m})$ (15) with those of neoplastic bone (from $0.1 \mu \mathrm{m}$ ) (82) or of mineralized cartilage as described here. Apart from the obvious difference in size, there are differences in spatial relationships to formative cells and to extracellular matrix. Moreover, it is important to realize that a calcospheritic pattern of mineralization is the only demonstrated means of mineralization for cartilage. Elsewhere, for example in bone and dentine $(18,22,62)$, an alternative mechanism exists to what some (59) see as either an early developmental or a pathological phase-both associated with rapid growth.

Some of the varied sites in which calcospherites have been described more re- 
cently are: the protozoan Spirostomum ambiguum (74); oyster exoskeleton (43); calcified cartilage of Ordovician vertebrates (35); mammalian circumpulpal dentine (13, $14,63)$; horse fetal (intramembranous) bone (19); rat femoral epiphyseal cartilage (15); calcifying, previously grafted human hyaline cartilage (64); healing bone in extraction sockets of rats (83); calcifying cartilage of human fetuses with Achondrogenesis Type I (71); human bone neoplasias (61, 82); chick tibiae in vivo and in vitro (36); and calcified cartilage in endoskeletal tesserae of modern sharks (56).

The actual process of spheritic calcification has been described by light microscopy in vertebrate mineralized tissues as leading to the formation of globular bodies in which crystallites are oriented so as to radiate from the center $(73,80)$. This crystallite arrangement was assumed to be independent of the collagen fibrils of the matrix. Transmission electron microscope (TEM) studies have drawn attention to the evi- dence for matrix vesicles $(1-3,5,11,12,88)$ as the initial sites of precipitation of calcium phosphate in hard tissue matrices. It is thought that crystallites form within the vesicles and accumulate in a radiating pattern as vesicle membranes rupture (79). In calcifying cartilage, the round crystal clusters increase in size $(25,81)$ and coalesce eventually to obscure the matrix (65).

We do not know the reason for the calcospherite size difference in cartilage described here. It is possible that the difference exists either as a function of relative distance from the mediating cell or because some characteristic of the extracellular space (chemical and/or structural) differs in the two locations. Attention has been drawn to chemical changes in ground substance preceding calcification $(39,94)$. The presence, size, and orientation of fibrils in perilacunar and interlacunar locations in articular cartilage have been reviewed (33). Unlike adult lamellar bone (18), calcified cartilage does not have an initial mineral-

FIgs. 1-9. SEMs of the articular aspect of the mineralized front of the cartilage plate of the mandibular condyle of young adult rats (264 days old).

FIG. 1. Low-magnification survey (of left mandibular condyle with anterior aspect to bottom of picture) showing mineralized cartilage completely covering condylar surface. Small amorphous patches (at arrows) contrast with the otherwise ubiquitous lacunar openings. Field width $=2.28 \mathrm{~mm}$.

Fig. 2. Enlargement of the central area in Fig. 1. Note lack of lacunar openings in the more amorphous patches to the right (arrows to same areas as in Fig. 1). Furrowing, presumably of vascular origin, runs diagonally from top right to bottom left. Field width $=1.11 \mathrm{~mm}$.

Fig. 3. Enlargement of the central area of Fig. 2. Mineralized lacunae are in different phases of completion from wide, shallow, open beds to completed, closed shells. Field width $=390 \mu \mathrm{m}$.

FIG. 4. An area of predominantly more complete lacunae. Stages in closure are numbered 1-5. Field width $=130 \mu \mathrm{m}$.

Fig. 5. An area showing the location of the differently sized calcospherites-larger, readily resolveable calcospherites (1) form the concave, inner walls and smaller calcospherites (s) constitute the outer, convex walls as a hardly resolveable filigree. Field width $=78 \mu \mathrm{m}$.

FIG. 6. Higher magnification of typical large calcospherites from an inner, concave wall of a mineralized chondrocyte lacuna (see Fig. 5). Thin, irregular, wavy plates showing preferred orientation radiate from the center of the mass. Field width $=5.57 \mu \mathrm{m}$.

Figs. 7-9. Stereo pairs; Figs. 8 and 9 are enlargements of the central areas of Figs. 7 and 8 .

FIG. 7. An open lacuna (o) to the lower right of the more central, closed lacuna (c) shows subsurface continuity with an adjacent lacuna and no intact floor. Note difficulty in resolving smaller calcospherites. Field width $=78 \mu \mathrm{m}$.

FIG. 8. Three-dimensional view of the outer convex wall of the completed lacuna (c) in Fig. 7. Note discontinuities in wall at the small arrows. Large arrow for Fig. 9. Field width $=26 \mu \mathrm{m}$.

FIG. 9. Higher magnification of typical smaller calcospherites forming the outer convex lacunar wall in Fig. 8. Constituent crystalline plates are fewer and thicker than in the large calcospherites. Large arrow to same point as in Fig. 8 for localization. Field width $=7.8 \mu \mathrm{m}$. 

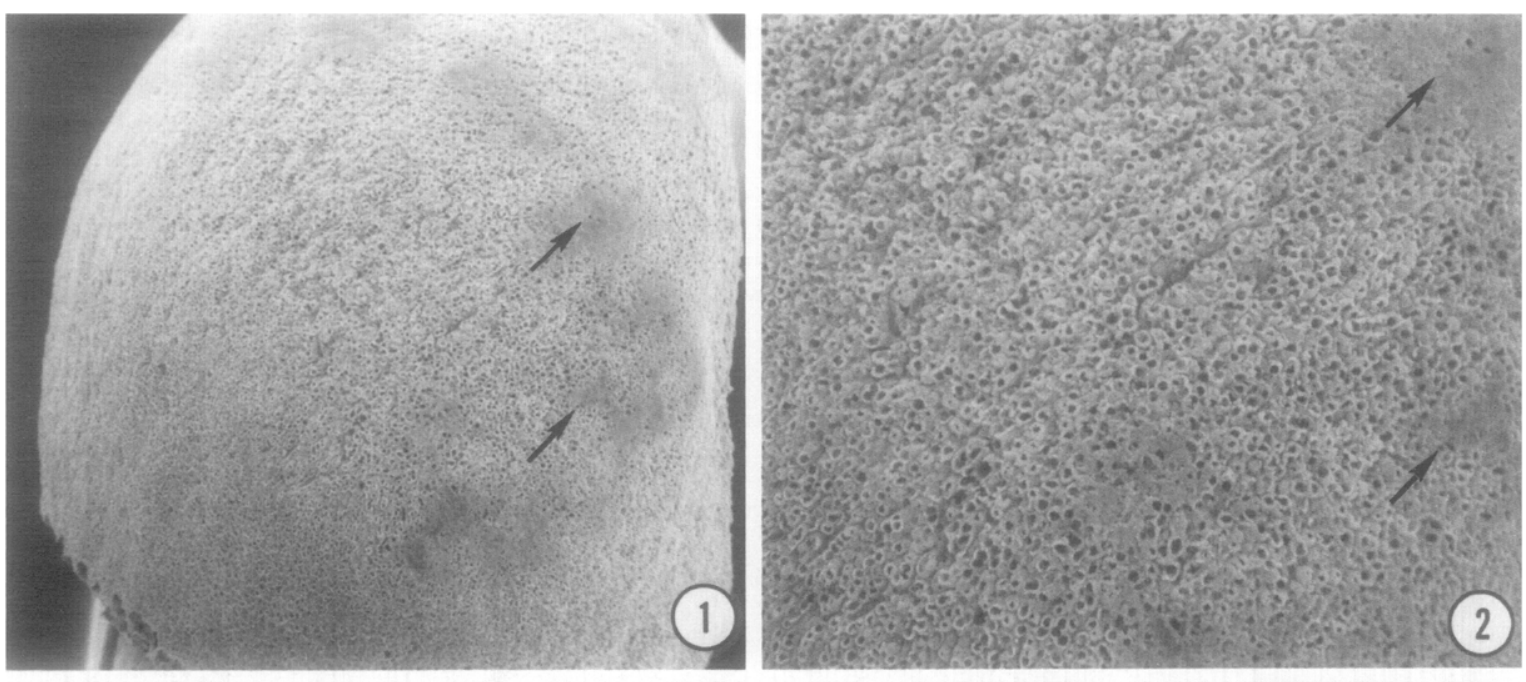

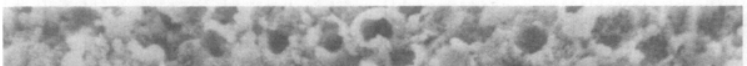

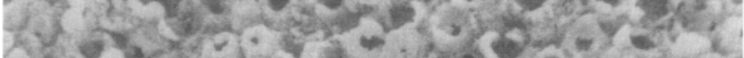

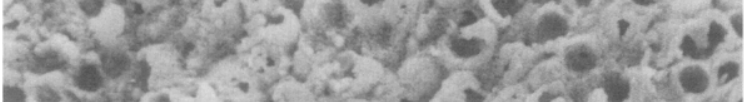

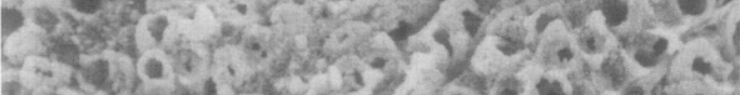

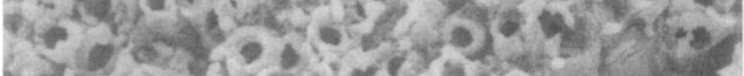

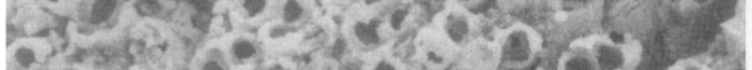

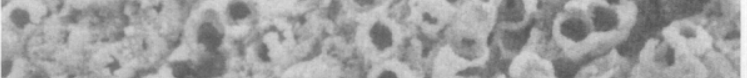

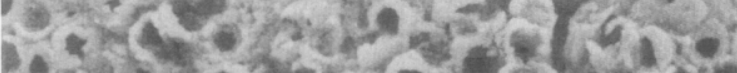

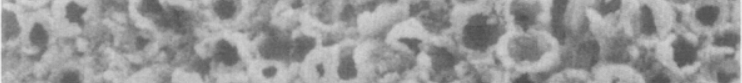

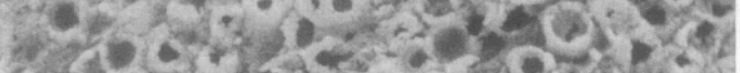
(c)

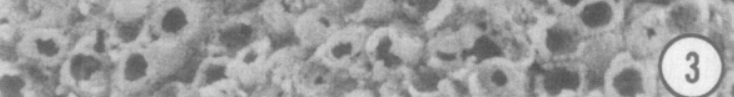
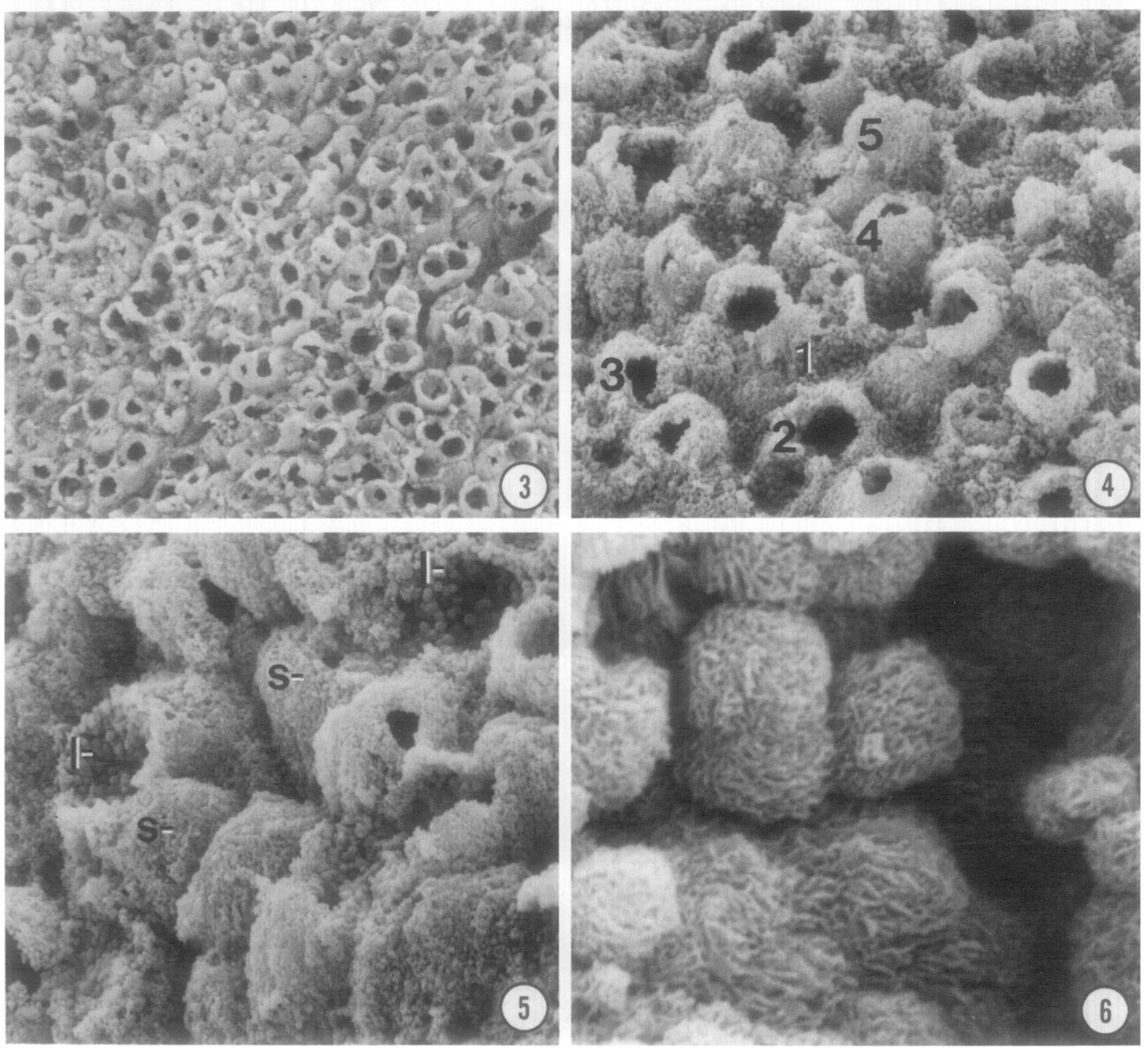

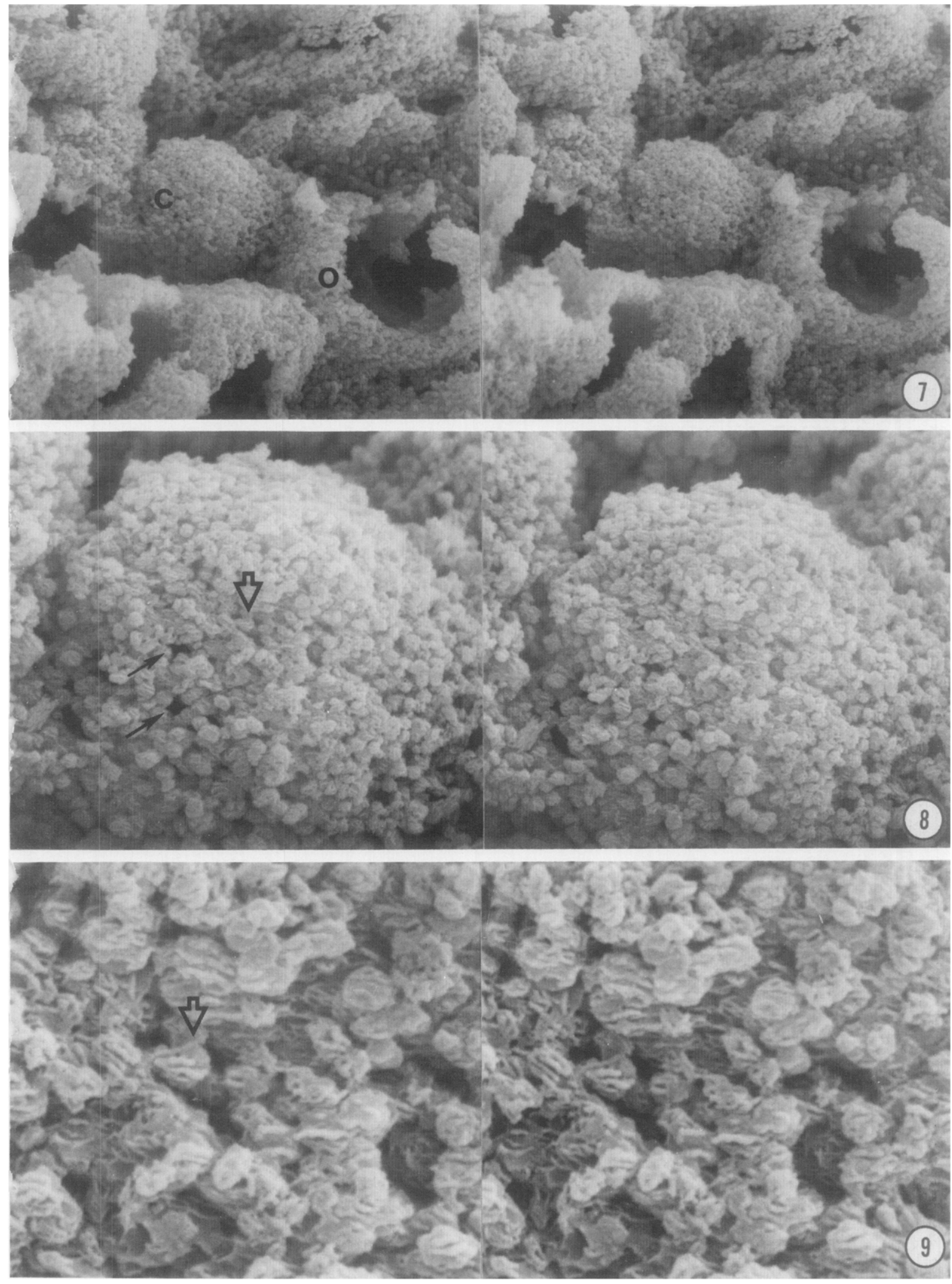

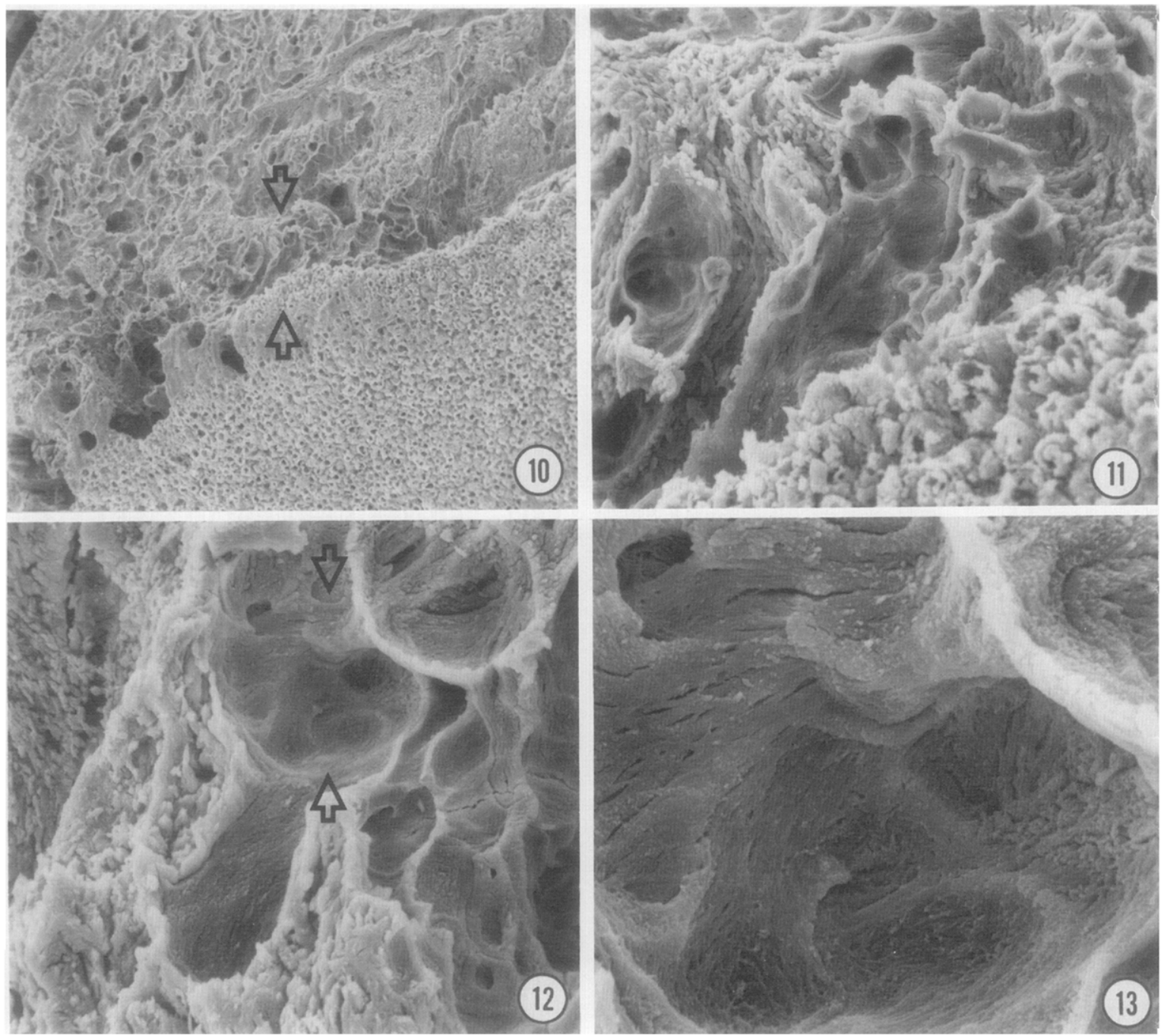

FIGS. 10-13. SEMs of the region of the junction of the mineralized cartilage plate of the mandibular condyle with the bone of the ramus of young adult rats (264 days old).

FIG. 10. The specimen is tilted so that the condyle is toward the bottom of the picture. The junction between the mineralized cartilage and bone is sudden and marked by lipping and large (presumably vascular) canals. Howship's lacunae are predominant on this subperiosteal bone surface of the ramus. Field width $=1.37 \mathrm{~mm}$.

FIG, 11. Higher magnification of area between arrows in Fig. 10. Howship's lacunae alternate with areas of repair (bone formation) immediately beneath the marginal lip of mineralized cartilage. Field width $=242.2 \mu \mathrm{m}$.

FIG. 12. Subperiosteal bone surface more distant from the mineralized condylar cartilage (localization for Fig. 13). Field width $=242 \mu \mathrm{m}$.

Fig, 13. Higher magnification of part of Fig. 12 (area between arrows) showing collagen fibril pattern and part of an osteocyte lacuna within resorption bay. Field width $=78 \mu \mathrm{m}$.

ization pattern which could be interpreted as fibril dependent (93). All reports indicate that a greater fibril density exists in the area where we find the smaller calcospherites. Calcospherite size difference in endo- skeletal tesserae has been noted as consistent with the supposition that growth proceeds in two directions within the one surface (56).

Concern has been expressed at the kind 
of preparation pictured here on a number of grounds $(16,37,77) ; \mathrm{NaOCl}$ may interact with the mineral component to change the size and shape of calcospherites; drying specimens to air may cause significant dimensional change; and a proportion of the as yet unfused calcospherites may be lost during washing of the specimen. It can be said in confident response to this that: favorable comparison has been made with specimens prepared with different organic solvents (e.g., 1:2 diaminoethane $(15,21)$ and hydrazine (17)) as well as with oxygen plasma ashed samples (17); calcium phosphates are insoluble at the $\mathrm{pH}$ of the $\mathrm{NaOCl}$ solution (17), and the inorganic component only is examined so that water loss from organic material and the shrinkage subsequent to it is minimized as a problem. It has been shown, however, that washing specimens dislodges some calcospherites from mineralizing surfaces (23). A further point is that our specimens were exposed to organic solvent for much longer than some studies-4 days as opposed to $2 \mathrm{hr}(82)$ and $4 \mathrm{hr}(71)$. The intent was to eliminate as much of the organic matrix as possible. The presence of an organic matrix within the crystallite clusters has been inferred by TEM studies (65).

The significance of these comments is that one could reasonably anticipate, in the natural state, fewer open chondrocyte lacunae and more, loosely attached, surface calcospherites than pictured here. The plate-like shape of the crystalline material constituting the calcospherites agrees with tilt experiments of TEM specimens. The extracellular crystalline phase has been likened to plaques or platelets which appear as rods or needles when viewed on edge (53, 59).

A secondary detail of "hollows and prominences" has been described by SEM both in the mandibular condyle of the guinea pig (5 to $15 \mu \mathrm{m}$ ) (86) and in hyaline articular cartilage $(20$ to $40 \mu \mathrm{m})(30,32,37,44,46$, $95)$. On the basis of the present anorganic material, we would agree that this repetitive "golf ball" pattern (49) could be accounted for by the size and profile of the chondrocyte lacunae (see Refs. (31) and (32) for a careful analysis). The interpretation assumes that, at least in the condyle, the unsupported, superficial layers of fibrous connective tissue would shrink back on to the mineralized cartilage plate under the vacuum conditions of examination. The variability in occurrence of this appearance (52) could be attributable to site, species, and age differences and to the unknown element of disease history amongst specimens.

Evolutionary arguments on the relative antiquity and contribution of bone and cartilage to the fully adult vertebrate skeleton have been reviewed elsewhere (56). The point is made that the significance of calcified cartilage as a connecting link is often ignored. These authors are certain of calcified cartilage as a primitive vertebrate hard tissue and note that the concept (78) that cartilage be considered only as an embryonic tissue adapted for growth has been questioned (7). Another (72), as a result of extensive review, finds bone, dentine, and globular calcified cartilage to be "equally old."

Consideration of this question in such general terms is relevant because the condylar cartilage of the mandible is accepted as phylogenetically and ontogenetically distinct from the primary cartilagenous skeleton $(38,69)$. Much has been made of the developmental role and histological characteristics of this cartilage plate and the question of its most appropriate classification $(38,67,75,84,85,91,92)$. The highly cellular nature, the relatively haphazard arrangement of lacunae, and the pericellular pattern of mineralization have prompted some to classify it as an immature, embryonic form of secondary cartilage (38). There is some question, however, as to the real value of such a classification. It has been put (66) that histological description and 
terminological rearrangement of themselves are "... not synonomous with an explanation of the growth processes of the cartilage." Be it a primitive or an embryonic characteristic, the cartilage plate in the rat maintains a mineralized front into the adult stage. No great emphasis has been put to date on the presence and integrity of this mineralized cartilage layer in adult mandibular condyles, reports varying with the species and the age of the specimen $(8,27,42$, $45,48,50,60)$.

The extensive osteoclastic activity in the bone of the ramus in the "normal" rat specimens pictured here (Figs. 10-13) was unexpected. It emphasizes the warning (9) that great care must be taken in confirming, through experimental work, induced remodeling changes on the basis of the mere sighting of osteoclasts in sectioned material. Normal morphological characteristics and likely variations from them should be known and considerable care taken to standardize orientation of specimen and plane of section.

There is considerable controversy over the question of adaptive remodeling of the temporomandibular joint as a response to altered functional demand (compare, for example, 4, 24, 26, 29, 40, 41, 47, 54, 76, 89). While extensive bone and cartilage remodeling have been described $(8,34,51,58,68$, 92), questions remain as to the relative roles of functional adaptation, normal aging, and pathological change. The present material is part of a survey of comparative differences in the presence, nature, and distribution of mineralized cartilage in mammalian condyles. It represents an attempt to provide a more realistic concept of the three-dimensional structure of the temporomandibular joint.

This study was supported by USPHS Grant DE 92731-13 and the Biomedical Research Support Programme of the University of Michigan School of Dentistry. The animals were kindly made available by Dr. J. Avery and Mr. H. Kazlaukas of the Dental Research Institute, University of Michigan. The microscopy was carried out in the EM laboratories of Dr. Bigelow,
Engineering Department, University of Michigan. We are happy to thank Dr. A. Boyde, University College London, for his helpful discussion of the manuscript.

\section{REFERENCES}

1. Anderson, H. C. (1969) J. Cell Biol. 41, 59-72.

2. Anderson, H. C. (1973) in Sognnaes, R. F., And Vaughan, J. M. (Eds.), Hard Tissue Growth, Repair and Remineralization, pp. 213-246, Associated Scientific Publications, Amsterdam.

3. Anderson, H. C. (1976) Fed. Proc. 35, 106-108.

4. BAUME, L. J., AND DerichsweIleR, H. (1961) Oral Surg. 14, 347-362.

5. Bernard, G. W. (1969) J. Dent. Res. 48, 781-788.

6. Bernard, G. W., and Pease, D. C. (1969) Amer. J. Anat. 125, 271-290.

7. Berril, N. J. (1955) The Origin of the Vertebrates, Oxford Univ. Press, London.

8. Blackwood, H. J. J. (1966) J. Dent. Res. 45, 480489.

9. Blankenship, J. R., AND RamfJoRd, S. P. (1976) J. Oral Rehab. 3, 83-99.

10. Bonucci, E. (1967) J. Ultrastruct. Res. 20, 33-50.

11. Bonucci, E. (1970) Z. Zellforsch. 103, 192-217.

12. Bonucci, E. (1971) Clin. Orthop. Rel. Res. 78, 108-139.

13. Boyde, A. (1968) in Fourth European Regional Conference on Electron Microscopy, pp. 427435, Rome.

14. Boyde, A. (1970) Apex 7, 9-16.

15. Boyde, A. (1972) in Bourne, G. H. (Ed.), The Biochemistry and Physiology of Bone, Vol. 1, 2nd ed., pp. 259-310, Academic Press, New York.

16. Boyde, A. (1976) in Johari, O., AND Becker, R. P. (Eds.), Scanning Electron Microscopy, pp. 683-690, IIT Research Institute, Chicago.

17. Boyde, A. (1980) Personal communication.

18. Boyde, A., ANd Hobdell, M. H. (1969) Z. Zellforsch. 93, 213-231.

19. Boyde, A., ANd Hobdell, M. H. (1969) Z. Zellforsch. 99, 98-108.

20. Boyde, A., ANd Jones, S. J. (1972) in Slavkin, H. C., ANd BavetTa, L. A. (Eds.), Developmental Aspects of Oral Biology, pp. 263-267, Academic Press, New York.

21. BoYde, A., AND LESTER, K. S. (1967) Z. Zellforsch. 83, 538-548.

22. Boyde, A., ANd REITH, E. J. (1969) Z. Zellforsch. 94, 479-486.

23. Boyde, A., ANd Sela, J. (1978) Calcif. Tissue Res, 26, 47-49.

24. Breitner, C. (1941) Amer. J. Orthodont. 27, 605632.

25. Cameron, D. A. (1963) Clin. Orthop. 26, 199-228.

26. Carlson, D., McNamara, J. A., and Jall, D. H. (1978) Amer. J. Anat. 151, 103-118. 
27. Carlsson, G. E., and Oberg, T. (1974) Oral Sci. Rev. 6, 53-86.

28. Charles, W. S. (1925) Brit. Dent. J. 46, 845-855.

29. Cimasoni, G. (1963) Oral Surg. Oral Med. Oral Pathol. 16, 613-621.

30. Clarke, I. C. (1971) J. Anat. 108, 23-30.

31. Clarke, I. C. (1971) J. Bone Joint Surg. 53B, $732-750$.

32. Clarke, I. C. (1973) in Johari, O., AND Corvin, I. (Eds.), Scanning Electron Microscopy, pp. 660-666, ITT Research Institute, Chicago.

33. Clarke, I. C. (1974) J. Anat. 118, 261-280.

34. Cran, J. A. (1976) Aust. Dent. J. 21, 423-429.

35. Denison, R. H. (1967) Fieldiana Geol. 16, 131192.

36. Dillaman, R. M., Wilbur, K. M., and CrenSHAw, M. A. (1979) Calcif. Tissue Int. 27, 3340.

37. Draenfrt, Y., AND Draenert, K. (1978) in JohaRI, O., AND BECkER, R. P. (Eds.), Scanning Electron Microscopy, Pt. II, pp. 759-766, SEM Inc., Illinois.

38. Durkin, J. F., Heeley, J. D., And Irving, J. T. (1973) in Melcher, A. H., AND Zarb, G. A. (Eds.), Oral Science Reviews, Vol. 6, pp. 27-29, Munksgaard, Copenhagen.

39. Dziewiatkowski, D. D., Tourtellotte, C. D., and Campo, R. D. (1968) in Quintarelli, G. (Ed.), The Chemical Physiology of Mucopolysaccharides, pp. 63-79, Little, Brown, Boston.

40. Folke, L. E., and Stallard, R. E. (1966) J. Periodont. Res. 1, 79-89.

41. Furstman, L. (1965) Amer. J. Orthodont. 51, 245261.

42. Furstman, L. (1966) d. Dent. Res. 45, 291-296.

43. Galstoff, P. S. (1964) Fish. Bull. 64, 74-110.

44. Gardner, D. L., AND Woodward, D. H. (1969) Ann. Dis. 28, 379-391.

45. Geering, A. H. (1978) Das Kiefergelenk im zahnartzlichprothetischen Fall, Karger, Basel.

46. Ghadially, F. N., Ghadially, J. A., Oryschak, A. F., And Young, N. K. (1977) J. Anat. 123, 527-536.

47. Gianelly, F. N., Ruben, M. P., and Risinger, R. (1970) J. Prosthet. Dent. 24, 629-635.

48. Griffin, C. J., Hawthorn, R., and Harris, R. (1975) in Griffin, C. J., and Harris, R. (Eds.), The Temporomandibular Joint Syndrome (Monogr. Oral Sci., Vol. 4), pp. 1-26, Karger, Basel.

49. Holt, P. J. L. (1975) in Holt, P. J. L. (Ed.), Current Topics in Connective Tissue Diseases, pp. 24-27, Churchill Livingstone, Edinburgh.

50. Ingervall, B., Carlsson, G. E., and ThilanDER, B. (1976) Acta Odont. Scand. 34, 133-139.

51. Ingervall, B., Fredén, H., and Heyden, G. (1972) Arch. Oral Biol. 17, 661-671.

52. JAGGer, R. G., and WhitTaker, D. K. (1977) J. Oral Rehab. 4, 377-385.
53. Johansen, E., And Parks, H. F. (1960) J. Biophys. Biochem. Cytol. 7, 743-746.

54. Jolly, M. (1961) Austral. Dent. J. 6, 243-256.

55. Kashiwa, H. K., And Komorous, J. (1971) Anat. Rec. 170, 119-127.

56. Kemp, N. E., And Westrin, S. K. (1979) J. Morphol. 160, 75-109.

57. Kessel, R. G., ANd Ǩardon, R. H. (1979) Tissues and Organs: A Text Atlas of Scanning Electron Microscopy, Freeman, San Fransisco.

58. Kreutziger, K. L., ANd Mahan, P. E. (1975) Oral Surg. Oral Med. Oral Pathol. 40, 165-181.

59. Landis, W. J., Paine, M. C., and Glimcher, M. J. (1977) J. Ultrastruct. Res. 59, 1-30.

60. Larsson, A. (1976) Anat. Rec. 185, 171-185.

61. Lee, W. R., Laurie, J., and Townsend, A. L. (1975) Cancer 36, 1414-1425.

62. Lester, K. S., AND Boyde, A. (1970) J. Ultrastruct. Res. 33, 80-94.

63. Lester, K. S., And Boyde, A. (1977) Brit. Dent. J. 143, 359-367.

64. MacConaill, M. A. (1973) J. Anat. 115, 23-27.

65. Martino, L. J., Yeager, V. L., and Taylor, J. J. (1979) Calcif. Tissue Int. 27, 57-64.

66. Meikle, M. C. (1973) Amer. J. Orthodont. 64, 5062.

67. Meikle, M. C. (1976) Arch. Oral Biol. 21, 33-43.

68. Moffett, B., Johnson, L. C., McCaBe, J. B., AND Askew, H. C. (1964) Amer. J. Anat. 115, 119142.

69. Noble, H. W. (1973) in Melcher, A. H., AND ZarB, G. A. (Eds.), Oral Science Reviews, Vol. 2, pp. 3-28, Munksgaard, Copenhagen.

70. Ornoy, A., and Langer, Y. (1978) Isr. J. Med. Sci. 14, 745-752.

71. Ornoy, A., Sekeles, E., Smith, P., Simkin, A., AND Koch, G. (1976) Amer. J. Pathol. 82, 7184.

72. Orvig, T. (1951) Ark. Zool. 2, 321-454.

73. Orvig, T. (1967) in Miles, A. E. W. (Ed.), Structural and Chemical Composition of Teeth, Vol. 1, pp. 45-110, Academic Press, New York.

74. Pautard, F. G. E. (1960) in Sognnaes, R. F. (Ed.), Calcification in Biological Systems, pp. 114, American Assoc. Advan. Sci., Washington, D.C.

75. Petrovic, A. G., Stutzmann, J. J., and Oudet, C. L. (1975) in McNamara, J. A. (Ed.), Determinants of Mandibular Form and Growth, pp. 101-153, Univ. of Michigan Press, Ann Arbor.

76. RamfJoRd, S. P., AND Enlow, R. D. (1971) $J$. Prosthet. Dent. 26, 517-531.

77. REDler, I., AND Zimny, M. L. (1974) in JoharI, O., AND CoRvin, I. (Eds.), Scanning Electron Microscopy, pp. 292-298, ITT Research Institute, Chicago.

78. Romer, A. S. (1942) Amer. Natur. 76, 394-404.

79. Sayegh, F. S., Solomon, G. S., And Davis, R. W. (1974) Clin. Orthop. Rel. Res. 99, 267-284. 
80. Schmidt, W. J., AND KeIL, A. (1958) Die gesunden und erkrankten Zahngewebe des Menschen und der Wirbeltiere im Polarisationmikroskop, p. 74, Carl Hunser, Munchen.

81. Scott, B. L., ANd Pease, D. L. (1956) Anat. Rec. 126, 465-495.

82. Sela, J. (1977) Calcif. Tissue Res. 23, 229-234.

83. Sela, J., ANd JaFFe, A. (1977) Acta Anat. 97, 241-247.

84. Silbermann, M., and Frommer, J. (1972) Amer. J. Anat. 135, 359-370.

85. Silbermann, M., And Frommer, J. (1973) Arch. Oral Biol. 18, 1549-1554.

86. Silva, D. G. (1971) Arch. Oral Biol. 16, 889-896.

87. Silva, D. G., and HaRT, J. A. L. (1967) J. Ultrastruct. Res. 20, 227-243.

88. Slavkin, H. C., Croissant, R., and Bringas, P. (1972) J. Cell Biol. 53, 841-849.
89. Stöckli, P. W., and Willert, H. G. (1971) Amer. J. Orthodont. 60, 142-155.

90. Sundstrom, B., and Takuma, S. (1971) J. Ultrastruct. Res. 36, 419-424.

91. Symons, N. B. B. (1965) Arch. Oral Biol. 10, 579 584 :

92. Thilander, B., Carlusson, G. E., Ingervall, B. (1976) Acta Odontol. Scand. 34, 117-126.

93. Thyвerg, J. (1974) J. Ultrastruct. Res. 46, 206218.

94. Thyberg, J., Lohmander, S., and Friberg, U. (1973) J. Ultrastruct. Res. 45, 407-427.

95. Walker, P. S., Sikorski, J., Dowson, D., LongFIELD, M. D., WRight, V., AND Buckley, T. (1969) Ann. Rheum. Dis. 28, 1-14.

96. Wright, D. M., And Moffetr, B. C. (1974) Amer. J. Anat. 141, 235-250. 